\title{
CAMA
}

Centre for Applied Macroeconomic Analysis

\section{What affects bank market power in the Euro area? A structural model approach}

\section{CAMA Working Paper 15/2021 January 2021}

\section{Paolo Coccorese}

Department of Economics and Statistics, University of Salerno, Italy

\section{Claudia Girardone}

Essex Business School, University of Essex, UK

\section{Sherrill Shaffer}

Department of Economics and Finance, University of Wyoming, USA

Centre for Applied Macroeconomic Analysis, ANU

\section{Abstract}

In this study we explore market power in 13 EU banking sectors for the years 2007 to 2019 by estimating a structural model with demand and supply equations, where the mark-up of price over marginal cost is parameterized as a measure of banks' conduct that depends on selected factors. Our evidence indicates that EU banks enjoy a significant degree of market power, which shows a decreasing trend over time and some difference across countries. More competition is associated with higher bank density, lower bank capitalization, more efficient and stable banking systems, and better macroeconomic conditions. Finally, a clear convergence pattern emerges in the behaviour of EU banks. 


\section{Keywords}

Banking, Market power, European integration

\section{JEL Classification}

C36, F36, G21, L10

\section{Address for correspondence:}

(E) cama.admin@anu.edu.au

\section{ISSN 2206-0332}

The Centre for Applied Macroeconomic Analysis in the Crawford School of Public Policy has been established to build strong links between professional macroeconomists. It provides a forum for quality macroeconomic research and discussion of policy issues between academia, government and the private sector.

The Crawford School of Public Policy is the Australian National University's public policy school, serving and influencing Australia, Asia and the Pacific through advanced policy research, graduate and executive education, and policy impact. 


\title{
What affects bank market power in the Euro area? A structural model approach
}

\author{
Paolo Coccorese \\ Department of Economics and Statistics, University of Salerno, Italy \\ Claudia Girardone \\ Essex Business School, University of Essex, UK \\ Sherrill Shaffer \\ Department of Economics and Finance, University of Wyoming, USA \\ Centre for Applied Macroeconomic Analysis, The Australian National University, Australia
}

\begin{abstract}
In this study we explore market power in 13 EU banking sectors for the years 2007 to 2019 by estimating a structural model with demand and supply equations, where the mark-up of price over marginal cost is parameterized as a measure of banks' conduct that depends on selected factors. Our evidence indicates that EU banks enjoy a significant degree of market power, which shows a decreasing trend over time and some difference across countries. More competition is associated with higher bank density, lower bank capitalization, more efficient and stable banking systems, and better macroeconomic conditions. Finally, a clear convergence pattern emerges in the behaviour of EU banks.
\end{abstract}

Keywords: Banking; Market power; European integration

JEL classification codes: C36; F36; G21; L10

\section{Corresponding author:}

Paolo Coccorese

Università degli Studi di Salerno

Dipartimento di Scienze Economiche e Statistiche

Via Giovanni Paolo II, 132 - 84084 Fisciano (SA) - Italy

Tel.: (+39) 089-962338 - Fax: (+39) 089-962049

E-mail: coccorese@unisa.it 


\section{Introduction}

The European Union has played a crucial role in building a common integrated market for member countries. One of the main objectives of integration was the enhancement of competition in the various economic sectors, with particular respect to price reductions in favour of consumers.

Such benefits have characterized also the banking industry of European nations. In this case, competition might have produced additional spillover effects on the involved economies, since lower prices mean better credit conditions on loans, which produce beneficial effects on investment, consumption, and hence economic growth. On the other side, banking markets are often characterized by significant market power of incumbents (due, e.g., to economies of scale, customer inertia, or informational asymmetries in credit relationships), which might generate substantial barriers for potential competitors.

Thus, it is not clear whether the more competitive environment of the various EU markets has involved also the banking sectors, or whether banks' market power remains substantial. From the 1990s, the banking industries in Europe have moved several steps towards a tighter integration. The adoption of the First and the Second Coordination Banking Directives allowed European banks to freely open branches in all member States, thus removing legal entry barriers and deregulating capital flows. Another important factor was the adoption of the single currency, which eliminated the exchange risk for banks.

As Weill (2013) notes, it is commonly accepted that those events have definitely promoted competition in the EU banking industry, but the empirical studies investigating this issue do not provide unambiguous results. For example, contrary to widespread thought, some studies have detected a decline of competition among banks (e.g., Fernandez de Guevara et al., 2005). However, many investigations have focused on the 1990s or the first years of 2000s, when regulatory reforms led to a series of (mainly domestic) mergers and acquisitions (M\&As) that reorganized the banking sectors in order to improve efficiency and performance. The picture may have changed in more recent years, when M\&As involving banks of different countries have risen in number and, especially, the Great Financial Crisis has dramatically hit the world economies, particularly financial markets and credit intermediaries.

This paper offers new evidence on the level and evolution of EU banks' market power in the very recent years, namely the period 2007-2019. Through a balanced panel dataset of 13 banking sectors that covers the largest economies belonging to the European Union, we therefore investigate 
the role of financial crisis, the subsequent recession, and the recovery period on their behaviour. Since all the considered countries have a common currency and are all subjected to the Single Supervisory Mechanism, we are able to avoid possible biases arising from the use of heterogeneous data. For achieving our purpose, we employ a structural model framework that provides an index measuring the competitiveness of oligopoly conduct at the country level. Being a non-structural measure of competition, it is directly estimated as a behavioural coefficient, without resorting to indirect proxies of competition (like market shares or concentration indices).

Several novelties characterize our study. First, the behavioural index that we estimate represents a clear and theoretically-founded measure of market power, and is built as a function of a number of factors both internal and external to the banking industry: to our knowledge, this approach has never been implemented before within the banking industry studies. Second, we estimate country-level measures of market power starting from country-level data, which allows to actually consider all banks of each country, whereas employing bank-level data normally discards several observations. Third, by means of our behavioural parameters, we perform a couple of convergence tests, to aim at assessing whether the possible specificities on single banking markets (with the related obstacles to the spreading of competition induced by the EU common market) are acting as a hurdle to reaching a homogeneous competitive environment during a period of time that starts from the global financial crisis and ends just before the uprising of the Covid pandemic. As a result, our analysis is able to offer valuable and up-to-date indications to policy makers as regards the effective progress of integration as well as possible supplementary measures to be implemented in order to further strengthen the banking union.

In what follows, Section 2 reviews the previous literature on banking competition, Section 3 presents the theoretical model, Section 4 provides a description of our empirical methodology, Section 5 discusses the empirical evidence on the degree of market power in the European banking markets, Section 6 examines its convergence across countries, and Section 7 concludes.

\section{Literature review}

Assessing market power in the banking industry has been a widely investigated topic in the latest economic literature, because of phenomena like financial market deregulation, M\&A activities, and the pervasive diffusion of technology, which all occurred in the last thirty years or so. Indeed, this research issue is crucial due especially to the effects of banks' market power on at least two "public goods": the stability of the banking industry, and the performance of the economy as a whole. 
Regarding the first aspect, the "competition-fragility view" states that rivalry among banks triggers a reduction of profit margins and thus encourages banks' risk taking, while the "competition-stability view" argues that more market power, by allowing banks to charge higher loan rates, is likely to increase bank risk because customers will find it harder to repay loans, thus amplifying adverse selection and moral hazard problems (Berger et al., 2009). Regarding the overall economic impact, a competitive banking market may reduce lending rates for borrowers and raise deposit rates for lenders, thus boosting both savings and investments, hence economic development, but may also shrink the supply of credit to informationally opaque borrowers, because of adverse selection and moral hazard, as well as reduce business risk diversification and the exploitation of economies of scale (Beck, 2015; Coccorese, 2017).

The empirical literature usually employs two different techniques for determining the level of competition - hence the degree of market power, the other side of the same coin - in the banking sector. According to the structural approach, based on the traditional "structure-conductperformance" (SCP) paradigm, in highly concentrated markets collusion is simpler and thus more likely to occur, therefore banks should gain higher profits. The "new empirical industrial organization" (NEIO) approach employs non-structural models of price and output determination for estimating a conduct parameter that measures the market power exercised by banks.

Given that the SCP paradigm predicts a positive relationship between industry structure and performance (e.g., Bain, 1951), it normally focuses on the estimation of a relationship between an index of market concentration and a measure of performance (profits or prices). However, the econometric evidence is rather mixed - for example, see Gilbert (1984), Weiss (1989), and Shaffer (2004) - and often does not support the framework's prediction.

The main characteristic of the NEIO approach is the direct assessment of firms' conduct by means of theoretically-based methodologies, hence ruling out indirect (and possibly ambiguous) inferences about market power drawn on concentration measures, yet requiring additional specific information on costs and demand. The most frequently adopted NEIO methods within the banking studies include the mark-up test, the H-statistic, the Lerner index, and the Boone indicator.

The mark-up test consists in the estimation of a simultaneous model of demand and supply equations that contains a conduct parameter quantifying the degree of banks' market power. It can be interpreted as either a conjectural variation coefficient or the deviation of the perceived marginal revenue schedule of a bank in the industry from the demand schedule, and its estimated level depends on the degree of market power prevailing in the industry (Iwata, 1974; Bresnahan, 1982; Lau, 1982). This method has been applied to banking data in several recent studies (e.g.: Toolsema, 2002; Coccorese, 2008; Delis et al., 2008; Rezitis, 2010; Qin and Shaffer, 2014; Mirza et al., 2016). 
The H-statistic, introduced by Panzar and Rosse (1987), is calculated as the sum of the estimated elasticities of revenues to factor prices. Although it has been used by many studies, recent work has increasingly discredited it as a reliable indicator of market power, to the point where it cannot now be considered a viable metric (Hyde and Perloff, 1995; Bikker et al., 2012; and especially Shaffer and Spierdijk, 2015); and therefore we do not use it here.

The Lerner index (Lerner, 1934) evaluates a bank's market power as a function of the difference between price and marginal cost (divided by price), which should be zero in perfectly competitive markets, but positive in presence of market power that allows banks to set prices above marginal cost (the latter being estimated from a standard cost function). One advantage of this index is to provide a bank-level measure of market power.

Lastly, the Boone indicator (Boone, 2008) is an industry-level figure, calculated on firm-level data as the elasticity of firms' profits with respect to their costs: higher values are likely to indicate more intense competition as long as the latter enables more efficient firms (i.e. those with lower marginal costs) to earn relatively higher profits or market shares than less efficient competitors.

In this study, we focus on the banking industries of 13 EU countries, and estimate a simultaneous equation model of demand and supply for loans based on Bresnahan (1982) and Lau (1982) so as to gauge the degree of market power of banks. We employ balanced panel data covering the years 2007 to 2019 . The novelty is that the behavioural index ordinarily provided by this model is built as a function of a number of structural and economic factors. This framework enables us to simultaneously identify the relevant determinants of the competitiveness of European banking markets, and hence their loan price.

In the literature analysing banking industries, other papers have tried to provide empirical evidence on the evolution and determinants of banks' market power. However, they have typically adopted a two-step sequential approach: first, a bank-level Lerner index is estimated; then, it is regressed over a number of banking and market observable characteristics.

Fernandez de Guevara et al. (2005) focus on the evolution of market power in the banking sectors of five European countries (France, Germany, Italy, Spain, and the United Kingdom) during the period 1992-1997. Overall, their results show that using concentration measures as proxy for the competition environment in banking markets may be misleading. Moreover, their estimated banklevel Lerner indices do not provide evidence of an increase in the degree of competition within the EU, and appear to increase with bank size, operating efficiency, loans-to-assets ratio, and economic expansion.

Fernandez de Guevara and Maudos (2007) concentrate on the Spanish banking system over the period 1986-2002 in order to analyse the explanatory factors of banks' market power. They find an 
increase of Lerner indices from the mid-1990s, and show that market power of banks is higher when they have a larger size (although such relation is non-linear), focus especially on the traditional intermediation activity, maintain lower liquidity, and are characterized by higher efficiency, while market concentration does not play a significant role.

Ayadi et al. (2010) investigate the determinants of market power (proxied by the Lerner index) in seven EU banking industries (Austria, France, Germany, Italy, Finland, Netherlands, and Spain) for the period 2000-2008. Overall, market power increases with market concentration, but decreases with the cost-to-income ratio (i.e. with cost inefficiency), capitalization (imputed to the fact that in the sample period, because of a rapid rise in asset prices, being leveraged might have contributed to greater profits), and branch network density.

Fungancova et al. (2010) examine bank competition in Russia by assessing the determinants of the Lerner index of local banks over the years 2001 to 2006. Their main findings are that competition has only slightly improved, although the average Lerner index is approximately the same of developed countries, and that banks' market power is positively influenced by market concentration, and negatively affected by risk (as measured by non-performing loans), while bigger bank size is associated with higher market power only up to a certain point (beyond which it becomes detrimental).

While studying bank penetration, market structure and banking conduct of Austrian banks in the year 2006, Burgstaller (2013) finds that their mark-ups (proxied by ad-hoc estimated Lerner indices) do not show any link with market concentration while are negatively related to bank office density, population density, and inefficiency.

Aiming at assessing the degree of market power in 17 Central and Eastern European banking markets in the years 2002 to 2010, Efthyvoulou and Yildirim (2014) find some convergence in country-level Lerner indices only up to the onset of the global financial crisis. Besides, market power is higher when banks are more operationally efficient, earn more income from non-interest sources, are better capitalized, and have a better asset quality.

Mirzaei and Moore (2014) investigate the determinants of bank competition for a large sample of countries in the period 1999-2011. They employ the country-level values of the Lerner index and the Boone indicator (as reported by the World Bank Global Financial Development Database), and find, among other things, that a more concentrated banking system faces greater competition in advanced economies but hampers competition in developing economies, and that market power is higher where per capita GDP is larger and bank credit grows slowly.

Rakshit and Bardhan (2019) consider a sample of 70 Indian commercial banks so as to measure and explain the degree of competition over the period 1996-2016. Their estimated Lerner indices 
show to be positively associated to operational efficiency, profitability, the share of non-interest income, capitalization, and GDP growth, while negatively related to the incidence of bad loans.

Aguilar and Portilla (2020) study the evolution and determinants of market power in Peru's regulated microfinance sector from January 2003 to June 2016 by means of both a conventional and an efficiency-adjusted Lerner index. Their main evidence is that both indices decreased until 2014 and then significantly grew, and that the largest companies as well as the more efficient ones are characterized by greater market power.

As stated above, we use the Bresnahan-Lau model to identify several factors that appear to affect market power in a group of EU banking sectors, through the estimation of a simultaneous two-equation system. In this light, the present study is one of the first attempts to employ such technique for the banking sector, and one of the few in the broader market power literature. Similar Bresnahan-Lau settings - i.e. with the behavioural parameter depending on external factors - have been developed only by Jans and Rosenbaum (1996) for the U.S. cement industry, Gallet (1997) for the U.S. rayon industry in the 1930s, and Coccorese and Pellecchia (2013) for investigating the role of multimarket contact within the Italian banking industry. In its basic design (i.e. with a unique conduct parameter), the Bresnahan-Lau mark-up model has been applied to the banking sector, among others, by Shaffer (1989, 1993), Suominen (1994), Toolsema (2002), Coccorese (2008), Delis et al. (2008), Rezitis (2010), Qin and Shaffer (2014), and Mirza et al. (2016).

Although this NEIO approach has a strong theoretical background and is able to overcome several limitations that characterize the SCP paradigm, it is not exempt from potential drawbacks. For example, Corts (1999) argues, both analytically and with simulations, that the conduct parameter derived within conjectural variation models may fail to measure market power accurately, while Perloff and Shen (2012) show that estimates based on the linear model inherently suffer from a severe multicollinearity problem, hence the estimated parameters in the optimality equation - including the market power parameter - might be imprecisely measured. The latter problem can be, nevertheless, mitigated if at least one of the equations has some other functional form.

\section{The model}

In our theoretical framework, a profit-maximizing bank chooses the level of output (here proxied by loans) so that marginal revenue equals marginal cost. In a market with $n$ banks, marginal revenue corresponds to the demand price under perfect competition, while it is equal to the marginal revenue of the whole industry in case of perfect collusion among all banks. 
For a given country $c$ at time $t$, the loan market demand is represented as

$$
Q_{c, t}=Q_{c, t}\left(P_{c, t}, \mathbf{X}_{c, t}, \boldsymbol{\delta}\right),
$$

where $Q_{c, t}$ is the aggregate level of loans, $P_{c, t}$ is the loan interest rate charged by local banks, $\mathbf{X}_{c, t}$ is a vector of exogenous variables affecting the demand curve, and $\delta$ is a vector of unknown parameters to be estimated.

The industry's true marginal revenue function is equal to

$$
M R_{c, t}=P_{c, t}+\frac{Q_{c, t}(\cdot)}{\frac{\partial Q_{c, t}(\cdot)}{\partial P_{c, t}}},
$$

while the perceived marginal revenue function for the generic bank $i$ operating in that country, and supplying the quantity of loans $q_{i, c, t}$, is

$$
M R_{i, c, t}=P_{c, t}+\lambda_{i, c, t} \frac{q_{i, c, t}(\cdot)}{\frac{\partial Q_{c, t}(\cdot)}{\partial P_{c, t}}} .
$$

The positive (unknown) parameter $\lambda_{i, c, t}$ measures the competitiveness of oligopoly conduct. Its value ranges from 0 to 1 : when $\lambda_{i, c, t}=0$, each bank acts as though marginal revenue coincides with market demand, so that price equals marginal cost and the behaviour is perfectly competitive; when $\lambda_{i, c, t}=1$, banks refer to the industry marginal revenue when setting price and output, which indicates joint monopoly or perfect collusion. Intermediate values of $\lambda_{i, c, t}$ denote various degrees of imperfect competition or market power, with aggregate output less than the competitive value. Negative values of $\lambda$ should reflect an unsustainable deviation from long-run equilibrium characterized by pricing below marginal cost; hence, aggregate output will exceed the competitive norm (Gruben and McComb, 2003; Shaffer, 2004).

The presence of individual $\lambda_{i, c, t}$ 's causes the overparametrization of this model, which can nonetheless be solved by aggregation. As a result, we are able to use country industry data for both demand and cost variables, and for each country the industry's marginal cost function $M C_{c, t}$ can now be interpreted as the horizontal summation of the $n$ banks' marginal cost functions (Shaffer, 2004, pp. 292-293). We are then left with a single parameter $\lambda_{c, t}$, which measures the average conduct of the banks operating in country/market $c$ at time $t$ (Bresnahan, 1989, pp. 1016-1017). 
After aggregating for the $n$ banks in the market, we can write the equilibrium condition $M R=M C$ as

$$
P_{c, t}+\lambda_{c, t} \frac{Q_{c, t}(\cdot)}{\frac{\partial Q_{c, t}(\cdot)}{\partial P_{c, t}}}=M C_{c, t},
$$

or else

$$
P_{c, t}-M C_{c, t}=-\frac{\lambda_{c, t}}{\eta_{c, t}}
$$

where $\eta_{c, t}=\frac{\partial Q_{c, t}(\cdot)}{\partial P_{c, t}} \frac{1}{Q_{c, t}(\cdot)}$ is the semi-elasticity of market demand with respect to price.

In Equation (5) we get a measure of the deviation of price from marginal cost $M C$, hence from the competitive price level. Shaffer (1993) proves that $-\lambda$ is also a local (or linear) approximation of the percentage deviation of total industry output from the optimal level of production that characterizes the competitive equilibrium.

As we aim at investigating the factors affecting banks' market power in European countries, we specify our behavioural index $\lambda_{c, t}$ as a function of a vector $\mathbf{Y}_{c, t}$ of industry and macroeconomic characteristics of country $c$ at time $t$ (to be specified later):

$$
\lambda_{c, t}=\lambda_{c, t}\left(\mathbf{Y}_{c, t}\right)
$$

Two important advantages of this empirical approach are the provision of an easily interpreted test statistic that encompasses the various oligopoly solution concepts, and the possibility to use industry aggregate data (Shaffer, 2004, p. 294). It is also able to capture any monopsony power (Shaffer, 1999, p. 191). It is worth noting that the model does not rely on any particular definition of local banking markets within a country. If each country in the sample actually comprises multiple local or regional markets, the estimate of $\lambda$ would represent the average degree of market power of the banks across those separate markets (Shaffer, 2001, p. 88).

Finally, if each nation in our sample spans a complete market (or set of markets), we would not expect any bias in our estimation of the market power parameter (Shaffer, 2001, p. 90); conversely, if some national economies in our sample are so open as to comprise less than a full market (that is, if cross-border competition is significant in the EU banking industry), the estimated market power parameter will overstate the true value and thus overstate the degree of market power (Shaffer, 
2001, pp. 90 and 99, footnote 7). Following the literature, we do not attempt to measure or control for such cross-border competition, but merely note its potential effect on the estimates. This sensitivity to the undermeasurement of complete markets is a possible disadvantage of the Bresnahan-Lau test, along with its requirements for nonlinear system estimation and data on aggregate industry demand.

We also acknowledge that, like various other tests for market power, it can be fooled by expense preference behaviour if banks choose to exercise some market power in the direction of inflating their costs rather than profits (Edwards, 1977; Shaffer, 2004, p. 297) As noted in Shaffer and Spierdijk (2017, p. 19), this measure is also closely related to measures proposed by Rothschild (1942), Genesove and Mullin (1998), and Wolfram (1999).

\section{Econometric specification}

For estimating the market power index $\lambda$, we need a simultaneous model that includes the demand equation (1) and the supply relation (5) where $\lambda_{c, t}$ is specified as in (6).

The demand function takes the following semi-logarithmic form (Lopez et al., 2002; Captain et al., 2007; Coccorese and Pellecchia, 2013):

$$
\ln Q_{c, t}=a_{0}+a_{1} P_{c, t}+a_{2} Z_{c, t}+a_{3} P O P_{c, t}+a_{4} Y P C_{c, t}+\varepsilon_{c, t} .
$$

In (7), $Q_{c, t}$ is the amount of loans provided in country $c$ and year $t, P_{c, t}$ is the average interest rate on loans, $Z_{c, t}$ is the interest rate of long-term government bonds (a proxy for the price of a substitute for bank loans; long-term bond yields guarantee some variability among countries, at the same time allowing to capture the specificities of each national financial market), $P O P_{c, t}$ measures the country population (a variable that accounts for the absolute market size), $Y P C_{c, t}$ represents the per capita Gross Domestic Product (which controls for the level of local income), and $\varepsilon_{c, t}$ is the error term.

Our choice of a semi-logarithmic demand function has the advantage of not imposing constant elasticities (which would happen when using the double-logarithmic functional form), a desirable assumption when dealing with time-series data. In addition, the estimation of the coefficient $a_{1}$ directly provides a measure of the average value of the price semi-elasticity of demand $\eta$.

Regarding the supply relation (5), we assume that marginal cost derives from a translog cost function (an acknowledged hypothesis in the analysis of banks' costs, consistent with substantial 
prior literature) with three generic inputs (deposits, $W_{1}$, labour, $W_{2}$, and capital, $W_{3}$ ) and one output (loans, $q$ ):

$$
\begin{aligned}
\ln t c_{i, c, t}=b_{0}+b_{q} \ln q_{i, c, t}+\sum_{h=1}^{3} b_{h} \ln W_{h, c, t}+b_{T} \ln T I M E+ \\
+\frac{1}{2}\left\{b_{q q}\left(\ln q_{i, c, t}\right)^{2}+\sum_{h=1}^{3} \sum_{k=1}^{3} b_{h k} \ln W_{h, c, t} \ln W_{k, c, t}+b_{T T}(\ln T I M E)^{2}\right\}+ \\
+\sum_{h=1}^{3} b_{q h} \ln q_{i, c, t} \ln W_{h, c, t}+b_{T q} \ln T I M E \ln q_{i, c, t}+\sum_{h=1}^{3} b_{T h} \ln T I M E \ln W_{h, c, t}+v_{i, c, t},
\end{aligned}
$$

where $t c_{i, c, t}$ and $q_{i, c, t}$ are bank $i$ 's total costs and output, respectively, $W_{h, c, t}(h=1,2,3)$ are the exogenous prices of the inputs, and TIME is a time trend included to capture the possible effects of technological change over banks in the sample period ${ }^{1}$ (Zardkoohi and Fraser, 1998).

In the translog cost function, the symmetry condition implies $\alpha_{h k}=\alpha_{k h}$. In addition, linear homogeneity in input prices requires that:

$$
\sum_{h=1}^{3} b_{h}=1, \sum_{k=1}^{3} b_{h k}=0(h=1,2,3), \sum_{h=1}^{3} b_{q h}=0, \sum_{h=1}^{3} b_{T h}=0 .
$$

We impose the previous conditions by dividing total costs and factor prices by $W_{3, c, t}$. Finally, for each country we aggregate across the banks operating therein, so that $\sum_{i=1}^{n} q_{i, c, t}=Q_{c, t}$ and $\sum_{i=1}^{n} t c_{i, c, t}=T C_{c, t}$. All the above leads to the following national translog cost function:

$$
\begin{aligned}
\ln & \frac{T C_{c, t}}{W_{3, c, t}}=b_{0}+b_{Q} \ln Q_{c, t}+\sum_{h=1}^{2} b_{h} \ln \left(\frac{W_{h, c, t}}{W_{3, c, t}}\right)+b_{T} \ln T I M E+ \\
& +\frac{1}{2}\left\{b_{Q Q}\left(\ln Q_{c, t}\right)^{2}+\sum_{h=1}^{2} \sum_{k=1}^{2} b_{h k}\left[\ln \left(\frac{W_{h, c, t}}{W_{3, c, t}}\right) \ln \left(\frac{W_{k, c, t}}{W_{3, c, t}}\right)\right]+b_{T T}(\ln T I M E)^{2}\right\}+ \\
& +\sum_{h=1}^{2} b_{Q h} \ln Q_{c, t} \ln \left(\frac{W_{h, c, t}}{W_{3, c, t}}\right)+b_{T Q} \ln T I M E \ln Q_{c, t}+\sum_{h=1}^{2} b_{T h} \ln T I M E \ln \left(\frac{W_{h, c, t}}{W_{3, c, t}}\right)+v_{c, t},
\end{aligned}
$$

and the resulting marginal cost function is:

\footnotetext{
${ }^{1}$ Our formulation of the cost function is consistent with the "intermediation approach", the most widely adopted in banking, for which deposits represent an intermediate input in the production of loans, in conjunction with other factors, as banks are regarded as a channel of funds from depositors to borrowers. An alternative concept, the "production approach," considers banks as firms producing a variety of services to customers, thus viewing both deposits and loans as outputs of banks. For more details, see Mester (2008), pp. 151-152.
} 


$$
M C_{c, t}=\frac{T C_{c, t}}{Q_{c, t}}\left[b_{Q}+b_{Q Q} \ln Q_{c, t}+b_{Q 1} \ln \left(\frac{W_{1, c, t}}{W_{3, c, t}}\right)+b_{Q 2} \ln \left(\frac{W_{2, c, t}}{W_{3, c, t}}\right)+b_{T Q} \ln T I M E\right] .
$$

At the country level, we measure the price of funds, $W_{1, c, t}$, through the average interest rate on deposits, the price of labour, $W_{2, c, t}$, as the ratio between banks' staff costs and the number of bank employees, and the price of capital, $W_{3, c, t}$, as the ratio between other administrative expenses and banks' total assets. Another advantage of using country-level aggregates becomes evident here, because the number of bank employees - while available at the country level - is typically not reported at the individual bank level. Thus, we are able to construct a theoretically correct measure of the price of labour, unlike cross-country bank-level studies. Total costs, $T C_{c, t}$, amount to the sum of the interest expenses, staff costs and other expenses, again at the country level.

Substituting (10) in (5), rearranging and considering the semi-logarithmic formulation of the demand equation, we can write:

$$
P_{c, t}=\frac{T C_{c, t}}{Q_{c, t}}\left[b_{Q}+b_{Q Q} \ln Q_{c, t}+b_{Q 1} \ln \left(\frac{W_{1, c, t}}{W_{3, c, t}}\right)+b_{Q 2} \ln \left(\frac{W_{2, c, t}}{W_{3, c, t}}\right)+b_{T Q} \ln T I M E\right]-\frac{\lambda_{c, t}}{a_{1}}
$$

Turning to the index of market power $\lambda_{c, t}$, it is specified as a function of a vector $\mathbf{Y}_{c, t}$ of six country-level variables that are hypothesized to affect banks' conduct, plus a series of year dummy variables (which allow to control for any systematic variation in market power throughout the sample period):

$$
\begin{aligned}
\lambda_{c, t}= & \lambda_{1} H H I_{c, t}+\lambda_{2} \text { BRPC }_{c, t}+\lambda_{3} E_{\text {EAST }}+\lambda_{c, t} \text { INEFF }_{c, t}+ \\
& +\lambda_{5} \text { ZSCORE }_{c, t}+\lambda_{6} G D P G R_{c, t}+\sum_{k=2007}^{2019} \lambda_{k} Y k
\end{aligned}
$$

The Herfindahl-Hirschman index $(H H I)$, here calculated on total assets, controls for the possibility that banks in more concentrated markets are able to exploit greater market power, in line with the SCP paradigm. The number of branches per thousand adult inhabitants (BRPC) is a proxy of branch density that allows to take into account the role of penetration of the banking system within the economy. We expect a negative sign of the related coefficient, since the number of banks in a market (hence, bank office density) is typically inversely related to the distance between the lender and the (closest) competing banks, which implies that more banks are likely to induce harsher competition and lower loan rates (Degryse and Ongena, 2005, p. 236). 
The ratio between total equity and total assets (EQAST) is added to control for the level of bank capitalization. We conjecture that better capitalized banks enjoy higher market power, because they have access to cheaper funds (due to the fact that their probability of failure is lower, which reduces the interest expenses on uninsured debt: see Berger, 1995, p. 435), suffer less from moral hazard problems, and may take more risk (with likely positive effects on revenues and profits). INEFF aims at capturing the impact of banks' operational inefficiency on market power, and is calculated as the ratio between non-interest expenses and total operating income (Fernandez de Guevara et al., 2005; Efthyvoulou and Yildirim, 2014). Such variable should exhibit a negative coefficient as long as less efficient banking industries (characterized by higher cost-to-income ratios) enjoy lower margins.

We also include the country-level Z-score (ZSCORE), a widely used indicator of overall bank stability (Boyd and Graham, 1986; Hannan and Hanweck, 1988; Boyd and Runkle, 1993; Maechler et al., 2007; Laeven and Levine, 2009; Demirgüç-Kunt and Huizinga, 2010; Delis and Kouretas, 2011; Beck et al., 2013; Fang et al., 2014; Lepetit and Strobel, 2015; Coccorese and Ferri, 2019). Particularly, it measures banks' distance-to-default: their individual insolvency risk is higher (i.e., they are financially less stable) when their Z-score is lower, and vice versa. The index is calculated as

$$
\operatorname{ZSCORE}_{c, t}=\frac{\operatorname{ROA}_{c, t}+E Q A S T_{c, t}}{\sigma_{R O A}},
$$

where $R O A_{c, t}$ is the average return on assets of banks in country $c$ at time $t, E Q A S T_{c, t}$ is their average equity-to-assets ratio, and $\sigma_{R O A}$ is the standard deviation of ROA over the years $t-2, t-1$ and $t$. ZSCORE may show either a positive or negative coefficient, depending on whether insolvency risk within the banking sector implies a higher or lower mark-up. A stable banking system (i.e. far from insolvency) allows banks to operate more comfortably especially with customers, with whom they can develop tighter relationships that are likely to increase their market power (Petersen and Rajan, 1995), although this is nonetheless a desirable outcome for borrowers that would not be otherwise financed. On the other side, more stable banking systems are also attractive and tend to induce entry from competitors (Kabir and Worthington, 2017, p. 119), which reduces incumbents' mark-up.

Finally, GDPGR is the real growth rate of GDP of each country, which reflects the business cycle and can indicate whether banks' market power varies with the macroeconomic conditions of each country. As Angelini and Cetorelli (2003) observe, banks' response to business cycle dynamics is not unambiguous. According to the model by Rotemberg and Saloner (1986), banks' 
mark-up is countercyclical, since a relatively high demand increases each participant's incentives to deviate from the agreement, thus a reduction of mark-ups is convenient for maintaining discipline. On the other side, following the model by Green and Porter (1984), lower levels of demand determine less business prospects for banks, which may lead to price wars in case banks misinterpret the fall in market demand as deviations from cooperative agreements, thus implying again a drop of mark-ups that are now cyclical. As long as banks' mark-up is countercyclical (cyclical), we should get a negative (positive) sign for GDPGR.

Substituting (12) in (11), we get:

$$
\begin{aligned}
& P_{c, t}=\frac{T C_{c, t}}{Q_{c, t}}\left[b_{Q}+b_{Q Q} \ln Q_{c, t}+b_{Q 1} \ln \left(\frac{W_{1, c, t}}{W_{3, c, t}}\right)+b_{Q 2} \ln \left(\frac{W_{2, c, t}}{W_{3, c, t}}\right)+b_{T Q} \ln T I M E\right]- \\
& -\frac{\lambda_{1} H H I_{c, t}+\lambda_{2} \text { BRPC }_{c, t}+\lambda_{3} E Q A S T_{c, t}+\lambda_{4} I N E F F_{c, t}}{a_{1}}- \\
& -\frac{\lambda_{5} Z S C O R E_{c, t}+\lambda_{6} G D P G R_{c, t}+\sum_{k=2007}^{2019} \lambda_{k} Y k}{a_{1}} .
\end{aligned}
$$

In summary, our system to be estimated is given by equations (7) and (14). Lau (1982) proves that a necessary and sufficient condition for the correct identification of the conduct parameter $\lambda$ in a system of demand and cost equations is that the demand function must not be separable in at least one exogenous variable that is included in the demand function but excluded from the marginal cost function. In our specification, this condition is met through the use of the semi-logarithmic demand function, since, for example, it is $\frac{\partial^{2} Q_{c, t}}{\partial P_{c, t} \partial P O P_{c, t}}=a_{1} a_{3} Q_{c, t} \neq 0$.

\section{Empirical evidence and discussion}

Our (balanced) dataset includes 13 EU countries (Austria, Belgium, Finland, France, Germany, Greece, Ireland, Italy, Netherlands, Portugal, Slovakia, Slovenia, Spain) for the period 2007 to 2019. Information on individual banking sectors come from various databases managed by the ECB (European Central Bank), particularly those regarding balance sheet items, consolidated banking data, MFI interest statistics, and banking structural financial indicators. Data on government interest rates, population and GDP have been collected from Eurostat (the EU statistical office). Economic figures have been converted into constant 2010 values by means of the GDP deflator. In Table 1 some descriptive statistics of the data are provided. 


\section{INSERT TABLE 1 ABOUT HERE}

We estimate our system of equations by non-linear three-stage least squares, thus assuming that their error terms are correlated across equations, but uncorrelated over time (Neven and Roller, 1999). Following the standard practice, we use all exogenous variables as instruments; because of the intrinsic endogeneity of $Q_{c, t}$ and $P_{c, t}$, we also use their first lagged values as instruments, so as to deal with possible problems of correlation between these variables and the error terms (Coccorese and Pellecchia, 2013).

We estimate four specifications of our model. We first treat the behavioural parameter $\lambda$ as a constant (i.e. $\lambda_{c, t}=\lambda_{0}$ ), thus resembling the customary Bresnahan-Lau mark-up test (Model 1). Then, we estimate three further systems where $\lambda_{c, t}$ is a function of: a) only the supposed explanatory variables HHI, BRPC, EQAST, INEFF, ZSCORE, and GDPGR (Model 2); b) only the year dummy variables (Model 3); c) both the country-level regressors and the year dummies (Model 4). The results of such estimations are shown in Table 2.

\section{INSERT TABLE 2 ABOUT HERE}

Regarding the demand equation, the values of the adjusted $R^{2}$ 's $(0.85)$ prove that the overall fit is good, while the coefficients of the explanatory variables are highly comparable across the two models, and are all significant at the $1 \%$ level.

The negative sign of the loan price, $P$, confirms the downward slope of the demand curve. The coefficient of $Z$ is positive, a signal that government bonds yield is a good proxy for the price of a substitute of bank loans. By calculating the elasticities of both $P$ and $Z$ (ranging between -0.51 and -0.55 , and between +0.40 and +0.45 , respectively), it appears that $\left|\varepsilon_{Q, P}\right|>\varepsilon Q, Z$ (see Table 2): because the cross-price elasticity is smaller than the own-price elasticity, we verify that European banks have succeeded in lessening price competition in their home markets through some combination of differentiating their products and providing fringe services to customers. ${ }^{2}$

Because the value of the own-price elasticity of demand is less than 1 in absolute value, it appears that banks are choosing to produce in the inelastic portion of the demand curve. A profitmaximizing equilibrium requires marginal cost (which is always positive) to equal marginal revenue (which however is negative for inelastic demand). Inelastic demand thus indicates some combination of the following conditions: (1) banks are not behaving in a profit-maximizing way but are pursuing some other financial objective such as size maximization; (2) the banking industry is not in equilibrium for some substantial portion of our sample; and/or (3) bank-level demand

\footnotetext{
${ }^{2}$ The standard errors of the elasticities have been calculated by means of the delta method. Details on the procedure are supplied in Appendix A.
} 
functions are substantially more elastic than the aggregate demand function, which would indicate a high level of competition (a low degree of market power). Below, we shall refine these initial impressions by looking at the estimated values of the index of competition.

The $P O P$ variable has a positive coefficient, so more populated markets are associated with higher loan demand, as we would expect. Finally, the coefficient of $Y P C$ is also positive, meaning that the level of per capita GDP has a constructive role in stimulating loan demand, again consistent with economic theory.

As regards the supply equation, we can notice that it is able to fit the data properly, since the adjusted $R^{2}$ equals 0.62 in Model 1 but reaches 0.79 in Model 4 . All coefficients of the marginal cost functions are significant at the $1 \%$ level, except $\ln Q$ (in Models 1 and 3) and $\ln T I M E$ (in Models 1 and 2).

In the same equation, we can now evaluate the behavioural parameters characterising European banks. In Model 1 (where $\lambda$ is held constant across countries and over time), the market power index is equal to 0.4983 , significantly different from both 0 and 1 at the $1 \%$ level of significance. The interpretation of this finding is that during the sample period the perceived marginal revenue of EU banks has been about 50 per cent of the marginal revenue that would be taken into consideration by a monopolistic firm or a perfect cartel. Having tested that $\lambda$ significantly differs from both zero and one, we can reject the hypotheses of both perfect collusion and perfect competition in the EU as a whole. Nonetheless, the value $\lambda=0.4983$ portrays a situation where European banks have a substantial market power: actually, considering that a symmetric Cournot equilibrium would generate $\lambda=1 / n$ (Bresnahan, 1982, p. 88), our point estimate of the conduct parameter corresponds roughly to a symmetric Cournot duopoly where just two banks divide the market evenly.

In Figure 1 we portray the average situation of European banking markets when $\lambda=0.4983$. All curves have been drawn starting from the estimated values of parameters of Model 1. The market equilibrium in the sample period is $\mathrm{E}$, where marginal cost $\mathrm{MC}$ equals perceived marginal revenue, corresponding to the (calculated) value of loans $(Q)$ of 570 thousand million euro at the aggregate country level. We can note that this figure is rather close to the median value of our sample (514 thousand million euro: see Table 1), and that European banks did not behave as joint profitmaximizing firms, since the equilibrium quantity is set where the industry's marginal revenue MR is negative, i.e. where the market demand was perceived to be inelastic (as we noted before). This evidence matches with our estimated own-price elasticity of demand (-0.5527). Actually, a collusive agreement among banks would have implied to set the quantity where marginal cost is equal to the industry's marginal revenue, i.e. point $\mathrm{M}$ (where $Q=346$ thousand million euro). Hence, we can reject the hypothesis of a monopoly conduct of European banks. 


\section{INSERT FIGURE 1 ABOUT HERE}

Nonetheless, we observe that their behaviour is far from being close to perfect competition, because in such situation, corresponding to point $\mathrm{C}$ in Figure 1 (where firms do not perceive any difference between their marginal revenue functions and demand function, thus acting as price takers and therefore setting a price equal to marginal cost), the calculated $Q$ would amount to 936 thousand million euro, about $64 \%$ more than the actual equilibrium. On this point, Figure 1 helps to demonstrate that $\lambda$ measures the gap between the perceived MR curve and the demand curve, relative to the distance between the industry's MR curve and the demand curve: as $\lambda=0.4983$, the perceived MR is about in the middle between the industry's marginal revenue curve and the market demand curve.

Since the estimation results are consistent across Models 2 to 4, we focus on the empirical evidence characterizing Model 4, i.e. the full specification, from which we can assess the impact of our selected factors on the behaviour of banks. There is no significant link between market concentration and market power, as the coefficient of $H H I$ is not statistically different from zero. Therefore, our results do not support the SCP paradigm (consistent with, among others: Fernandez de Guevara et al., 2005; Fernandez de Guevara and Maudos, 2007; Anzoategui et al., 2010; Delis, 2012; Efthyvoulou and Yildirim, 2014; Rakshit and Bardhan, 2019), while it suggests that in concentrated markets banks may not be able to exploit market power advantages.

In line with prior literature (Angelini and Cetorelli, 2003; Casu and Girardone, 2006; Coccorese, 2008; Ayadi et al., 2010; Burgstaller, 2013), the variable BRPC shows a negative and significant coefficient, meaning that a higher number of branches per inhabitants, by likely implying a stronger local competition among banks, reduces their market power. On the contrary, more capitalized banking systems are characterized by higher market power, as the EQAST variable exhibit a positive and significant coefficient, an evidence that corroborates previous findings (Delis, 2012; Ghosh, 2018; Rakshit and Bardhan, 2019). Hence, better capitalized banks are able to get higher margins due to higher loan rates (linked to the possibility of acquiring riskier assets) and/or lower deposit rates (deriving from lower bankruptcy costs for customers that imply lower funding expenses).

The coefficient of INEFF is negative and significant (at the 10\% level in Model 2): the evidence is that more efficient banks (i.e. those with lower operating inefficiency) enjoy higher market power (Fernandez de Guevara et al., 2005; Ayadi et al., 2010; Cubillas and Suarez, 2013; Efthyvoulou and Yildirim, 2014; Ghosh, 2018; Aguilar and Portilla, 2020), reasonably thanks to better management or superior production technologies. We therefore get support to the efficient structure hypothesis, according to which improving efficiency leads to higher profits through preventing competition 
from other banks (Fernandez de Guevara and Maudos, 2007, p. 291). On the contrary, a higher stability of the banking industry, as measured by the Z-score, is significantly associated with lower market power, as the negative coefficient of ZSCORE (significant at the 5\% level) indicates. Therefore, pursuing stability at the industry level is a relevant factor for enhancing competition and reducing banks' rents. This result clearly corroborates the "competition-stability view" (Berger et al., 2009).

Finally, the countries' economic performance also affects the behaviour of banks; particularly, since the coefficient of GDPGR is negative and significantly different from zero, banks' market power tends to decrease with the improvement of macroeconomic conditions (Rotemberg and Saloner, 1986; Toolsema, 2004). This result indicates that in prosperous times the possibility of extending lending activities increases competition among banks and hence reduces mark-ups, while in periods characterized by low economic growth there is an increase of their market power and a corresponding reduction of competitiveness within banking systems.

At the bottom of Table 2 we have reported the estimated price elasticity with respect to each of the explanatory variables associated to the behavioural index, in order to gauge their individual effects on banks' competitive conduct. Among them, we note that the most significant figure characterizes the equity-to-assets ratio (EQAST): the value of $\varepsilon_{P, E Q A S T}$ is about 0.48 , which means that a $10 \%$ increase of EQAST is associated with an increase of about $4.8 \%$ in the value of the loan interest rate charged by banks. So, for example, if the equity-to-assets ratio raises from the median value (6.7092) to the third quartile (7.8244), corresponding to $+16.6 \%$, the price would increase by about $8 \%$. Since the third quartile of $P$ (4.6858) is $29 \%$ higher than its median (3.6313), we conclude that the effect of a better capitalization of banks on loan price cannot be considered as negligible in magnitude.

In both Models 3 and 4, year dummies help to find out that market power has declined almost monotonically during the sample period, likely reflecting regulatory and supervisory steps aimed at improving competition, while perhaps initially reflecting an impact of the global financial crisis as well. This is good news for policy makers because there has been a contrary fear that consolidation (especially following the onset of the crisis) might have weakened competition.

Building in the specification of $\lambda$ as presented in Equation (12), we are able to compute different $\lambda_{c, t}$ 's for the various countries and years. At the bottom of Table 2 we report the average, the minimum and the maximum values of such $\lambda_{c, t}$ ss: as it is evident, all of them are positive and fall into the theoretical zero-one interval. Based on the estimation results of Model 4, in Table 3 we provide the estimated indices of market power for all countries and years. We again note that, on average, the mark-up index noticeably decreases during the period 2007-2012, when the global 
financial crisis severely hit Europe with ensuing economic consequences. This indication matches with the evidence by Weill (2013), even if the latter is based on the calculation of the Lerner index for EU countries at the bank level.

\section{INSERT TABLE 3 ABOUT HERE}

Slovakia and Slovenia, representing the last sample countries to have joined the European Union (in May 2004), show the highest values of $\lambda$ over the sample period (about 0.50 or more), while the lowest average level characterizes Spain, Germany, and France ( 0.30 or less).

Greece and Ireland also show an outstanding mean of the behavioural index throughout 20072019 (about 0.45). Together with Portugal and Spain, those countries were heavily hit by the European sovereign debt crisis. Not casually, all such four countries reached their minimum of $\lambda$ between 2011 and 2012, i.e. when the debt crisis reached its peak.

After 2012, countries showing an increasing pattern of $\lambda$ are Ireland, Slovenia, Greece, and, to a lesser extent, Spain and Portugal. For Austria and Belgium, the lowest value of the behavioural parameter is attained in 2012 as well, but in the following years it remains quite low. For all the other countries, $\lambda$ is at its minimum between 2016 and 2019.

\section{A test of convergence of banks' market power across the EU}

The pattern of the various $\lambda_{c, t}$ 's, shown in Table 3, does not allow a clear understanding about the existence of convergence (or divergence) in market power of banks across EU countries, particularly because it exhibits important fluctuations during the sample period.

One of the aims of the European Union has undoubtedly been financial integration among member countries since, by designing a homogeneous framework of rules, it could have created further opportunities to firms and customers. Capital flows, for example, have actually exhibited a steady growth of volume. Nonetheless, financial integration was also believed to stimulate competition, particularly in the banking sector as a consequence of the removal of entry barriers, the reduction of existing excess capacity, enhanced geographical diversification, and increased concentration through M\&As (Casu and Girardone, 2009). Yet, the global financial crisis of 2007 adversely affected financial integration in the EU, which particularly suffered the effects of the sovereign debt crisis that started in 2010. In this period, massive state aid - in terms of recapitalization and impaired asset measures - surely limited the competitive forces among banks (Maudos and Vives, 2019). 
In this section we aim at testing the presence of convergence among our EU country members with respect to banks' market power. Empirical traces of such convergence would represent an important signal of the ongoing achievement of financial integration in the Euro area.

To assess whether banks' conduct in each country is converging to the EU average level, we consider two notions of convergence, $\beta$-convergence and $\sigma$-convergence (Barro and Sala-i-Martin, 1991), which are common in the growth literature. In our framework, we have $\beta$-convergence if countries where banks have less market power tend to catch up with those where banks' enjoy a higher value of $\lambda$, while we have $\sigma$-convergence if the dispersion of our conduct measure across countries shows a declining trend over time. These indicators are the most adopted in the analysis of convergence, and are complementary but not excludable: actually, $\beta$-convergence is a necessary but not a sufficient condition for $\sigma$-convergence to take place (Weill, 2013, p. 104).

In econometric terms, the $\beta$-convergence test involves a regression of the growth rate of the mark-up variable on its initial value, whereas the $\sigma$-convergence test is performed by regressing the variation of the difference between the conduct parameter and its average EU level on its starting level. In both cases, we have convergence if the dependent variable is negatively correlated with the start-of-period value.

Given the characteristics of our sample, we employ panel data specifications of both convergence tests. More in depth, $\beta$-convergence is assessed by estimating the following equation (Canova and Marcet, 1995):

$$
\ln \lambda_{c, t}-\ln \lambda_{c, t-1}=c_{o}+c_{1} \ln \lambda_{c, t-1}+\sum_{i=1}^{N} \gamma_{i}
$$

where $\gamma_{i}$ are fixed effects for the $N$ countries entering Equation (15). As told, there is $\beta$-convergence if the coefficient $c_{1}$ of the initial level of $\lambda$ is negative, as this implies a convergence effect toward the initial level.

The specification of the $\sigma$-convergence test is as follows (Parikh and Shibata, 2004):

$$
\Delta W_{c, t}=d_{0}+d_{1} W_{c, t-1}+\sum_{i=1}^{N} \gamma_{i},
$$

with $\Delta W_{c, t}=W_{c, t}-W_{c, t-1}$ and $W_{c, t}=\ln \lambda_{c, t}-$ mean $\left(\ln \lambda_{t}\right)$, while $\gamma_{i}$ is again a set of dummies that is added to capture the country effects. Now, there is $\sigma$-convergence if $d_{1}<0$.

Table 4 reports the results of the convergence tests. Both $c_{1}$ and $d_{1}$ exhibit negative and highly significant values, thus supporting the hypothesis of convergence of banks' behaviour in EU 
countries. We interpret this evidence as a signal of increasing banking integration, in terms of a reduction of both the differences in banks' market power across countries ( $\beta$-convergence) and the dispersion of the mean values of $\lambda$ between countries during the sample period ( $\sigma$-convergence).

\section{INSERT TABLE 4 ABOUT HERE}

Our evidence confirms the findings of previous studies assessing convergence towards similar competitive behaviour in European banking industries (e.g.: Andries and Capraru, 2012; Weill, 2013; Lapteacru, 2018; Karadima and Louri, 2020). In terms of integration, this is a reassuring result especially considering the period under study, since there was some jeopardy that the global financial crisis led to competition bias because of state aid granted to banks in several countries.

\section{Conclusions}

The ongoing economic integration in the EU markets is expected to deliver important benefits to member states. Among them, the development of banking competition is certainly one of the most important, since banks play a critical role in the economy: a lower degree of market power induced by a more competitive framework would allow lower prices of the various financial services, therefore boosting credit, investment and growth. Few studies have analysed banks' market power in the most recent years, when the EU markets have suffered from the global financial crisis and credit institutions have been exposed to serious pressures and troubles. Indeed, many of those economies have struggled to recover prior performance levels, even after much time.

Accordingly, this paper has studied the evolution of market power in the banking sectors of 13 EU countries over the years 2007 to 2019, i.e. those covering the global financial crisis and its aftermath, also providing some evidence on its convergence among nations. We have estimated a simultaneous equation model, where the excess of price over marginal cost - measuring banks' market power - has been considered as a function of a vector of variables, in order to identify observable factors that have the potential to increase or lessen it.

Our results show that EU banks have been able to maintain an appreciable degree of market power, even if it seems to have decreased during the sample period. In addition, market power generally appears higher in case of less widespread branch networks, more capitalized but less efficient or less stable banking systems, and more difficult macroeconomic conditions. Two separate tests provide a clear indication of convergence in the behaviour of banks across EU countries. 
The nonetheless substantial market power of banks can be ascribed to the unique characteristics of banking markets, where asymmetric information motivates close lending relationships between customers and banks, which allow the former to maintain access to credit even in difficult times but enable the latter to impose significant market power on its clientele. Yet, the clear evidence of some ongoing convergence of competition among EU banking sectors over the last years may be regarded as a success of the integration accomplished since the Nineties. 


\section{References}

Aguilar, G., Portilla, J., 2020. Determinants of market power in the Peruvian regulated microfinance sector. Journal of Industry, Competition and Trade, 20(4), 657-688.

Andries, A.M., Capraru, B., 2012. Competition and efficiency in EU27 banking systems. Baltic Journal of Economics, 12(1), 41-60.

Angelini, P., Cetorelli, N., 2003. The effects of regulatory reform on competition in the banking industry. Journal of Money, Credit, and Banking, 35(5), 663-684.

Anzoategui, D., Martinez Peria, M.S., Rocha, R.R., 2010. Bank competition in the Middle East and Northern Africa region. Review of Middle East Economics and Finance, 6(2), 1-23.

Ayadi, R., Llewellyn, D.T., Schmidt, R.H., Arbak, E., De Groen, W.P., 2010. Investigating Diversity in the Banking Sector in Europe. Key Developments, Performance and Role of Cooperative Banks. Brussels: Centre for European Policy Studies.

Bain, J.S., 1951. Relation of profit rate to industrial concentration: American manufacturing, 1936-40. Quarterly Journal of Economics, 65(3), 293-324.

Barro, R., Sala-I-Martin, X., 1991. Convergence across states and regions. Brookings Papers on Economic Activity, 22(1), 107-182.

Beck T., 2015. Bank competition: Winning isn't everything. Financial World, February-March, 2427.

Beck, T., De Jonghe, O., Schepens G., 2013. Bank competition and stability: Cross-country heterogeneity. Journal of Financial Intermediation, 22(2), 218-244.

Berger, A.N., 1995. The relationship between capital and earnings in banking, Journal of Money, Credit, and Banking, 27 (2), 432-456.

Berger, A.N., Klapper, L.F., Turk-Ariss, R., 2009. Bank competition and financial stability. Journal of Financial Services Research, 35(2), 99-118.

Bikker J.A., Shaffer S., Spierdijk, L., 2012. Assessing competition with the Panzar-Rosse model: The role of scale, costs, and equilibrium. Review of Economics and Statistics, 94(4), 10251044.

Boone, J., 2008. A new way to measure competition. Economic Journal, 118(531), 1245-1261.

Boyd, J.H., Graham, S.L., 1986. Risk, regulation and bank holding expansion into nonbanking. Federal Reserve Bank of Minneapolis Quarterly Review, 10, 2-17.

Boyd, J.H., Runkle, D.E., 1993. Size and performance of banking firms. Testing the predictions of theory. Journal of Monetary Economics, 31(1). 47-67.

Bresnahan, T.F., 1982. The oligopoly solution concept is identified. Economics Letters, 10(1-2), 87-92. 
Bresnahan, T.F., 1989. Empirical studies of industries with market power. In: Schmalensee, R., Willig, R.D. (Eds.), Handbook of Industrial Organisation, Vol. 2. Amsterdam: Elsevier, North-Holland, 1011-1057.

Burgstaller, J., 2013. Bank office outreach, structure and performance in regional banking markets. Regional Studies, 47(7), 1131-1155.

Canova, F., Marcet, A., 1995. The poor stay poor: Non-convergence across countries and regions. CEPR Discussion Papers, No. 1265, London.

Captain, P.F., Good, D.H., Sickles, R.C., Ayyar, A., 2007. What if the European airline industry had deregulated in 1979? A counterfactual dynamic simulation. In: Lee, D. (Ed.), The Economics of Airline Institutions, Vol. 2, Amsterdam: Elsevier, North Holland, 125-146.

Casu, B., Girardone, C., 2006. Bank competition, concentration and efficiency in the single European market. The Manchester School, 74(4), 441-468.

Casu, B., Girardone, C., 2009. Competition issues in European banking. Journal of Financial Regulation and Compliance, 17(2), 119-133.

Coccorese, P., 2008. Bank competition and regional differences. Economics Letters, 101(1), 13-16. Coccorese, P., 2017. Banking competition and economic growth. In: Bikker, J.A., Spierdijk, L. (Eds.), Handbook of Competition in Banking and Finance. Cheltenham: Edward Elgar, 230263.

Coccorese, P., Ferri, G., 2019. Is competition among cooperative banks a negative sum game?, Journal of Institutional Economics, 15(4), 673-694.

Coccorese, P., Pellecchia, A., 2013. Multimarket contact, competition and pricing in banking. Journal of International Money and Finance, 37, 187-214.

Corts, K.S., 1999. Conduct parameters and the measurement of market power. Journal of Econometrics, 88(2), 227-250.

Cubillas, E., Suarez, N., 2013. Bank market power after a banking crisis: Some international evidence. Spanish Review of Financial Economics, 11(1), 13-28.

Degryse, H., Ongena, S., 2005. Distance, lending relationships, and competition. Journal of Finance, 60(1), 231-266.

Delis, M.D., 2012. Bank competition, financial reform, and institutions: The importance of being developed. Journal of Development Economics, 97(2), 450-465.

Delis, M.D., Kouretas, G.P., 2011. Interest rate and bank risk-taking. Journal of Banking and Finance, 35(4), 840-855.

Delis, M.D., Staikouras, K.C., Varlagas, P.T., 2008. On the measurement of market power in the banking industry. Journal of Business Finance and Accounting, 35(7-8), 1023-1047. 
Demirgüç-Kunt, A., Huizinga H.P., 2010. Bank activity and funding strategies. The impact on risk and returns. Journal of Financial Economics, 98(3), 626-650.

Edwards, F.R., 1977. Managerial objectives in regulated industries: Expense-preference behavior in banking. Journal of Political Economy, 85(1), 147-162.

Efthyvoulou, G., Yildirim, C., 2014. Market power in CEE banking sectors and the impact of the global financial crisis. Journal of Banking and Finance, 40, 11-27.

Fang, Y., Hasan, I., Marton, K., 2014. Institutional development and bank stability: Evidence from transition countries. Journal of Banking and Finance, 39, 160-176.

Fernandez de Guevara, J., Maudos, J., 2007. Explanatory factors of market power in the banking system. The Manchester School, 75(3), 275-296.

Fernandez de Guevara, J., Maudos, J., Perez, F., 2005. Market power in European banking sectors. Journal of Financial Services Research, 27(2), 109-137.

Fungacova, Z., Solanko, L., Weill, L., 2010. Market power in the Russian banking industry. International Economics, 124, 127-146.

Gallet, C.A., 1997. Public policy and market power in the rayon industry. Journal of Economics and Business, 49(4), 369-377.

Genesove, D., Mullin, W.P., 1998. Testing static oligopoly models: Conduct and cost in the sugar industry, 1890-1914. RAND Journal of Economics, 29(2), 355-377.

Ghosh, A., 2018. What drives banking industry competition in developing countries?. Journal of Economic Development, 43(4), 1-20.

Gilbert, R.A., 1984. Bank market structure and competition: A survey. Journal of Money, Credit, and Banking, 16(4), 617-645.

Green, E.J., Porter, R.H., 1984. Noncooperative collusion under imperfect price information. Econometrica, 52(1), 87-100.

Greene, W.H., 2012. Econometric Analysis. 7th Edition. New Jersey: Prentice Hall.

Gruben, W.C., McComb, R.P., 2003. Privatization, competition, and supercompetition in the Mexican commercial banking system. Journal of Banking and Finance, 27(2), 229-249.

Hannan, T.H., Hanweck, G.A., 1988. Bank insolvency risk and the market for large certificates of deposit. Journal of Money Credit and Banking, 20(2), 203-211.

Hyde, C.E., Perloff, J.M., 1995. Can market power be estimated? Review of Industrial Organization, 10(4), 465-485.

Iwata, G., 1974. Measurement of conjectural variations in oligopoly. Econometrica, 42(5), 947-966.

Jans, I., Rosenbaum, D.I., 1996. Multimarket contact and pricing: evidence from the U.S. cement industry. International Journal of Industrial Organization, 15(3), 391-412. 
Kabir, M.N., Worthington, A.C., 2017. The 'competition-stability/fragility' nexus: A comparative analysis of Islamic and conventional banks. International Review of Financial Analysis, 50, 111-128.

Karadima, M., Louri, H., 2020. Bank competition and credit risk in Euro Area banking: fragmentation and convergence dynamics. Journal of Risk and Financial Management, 13(57), 1-28.

Laeven, L., Levine, R., 2009. Bank governance, regulation and risk taking. Journal of Financial Economics, 93(2), 259-275.

Lapteacru, I., 2018. Convergence of bank competition in Central and Eastern European countries: do foreign and domestic banks go hand in hand?. Post-Communist Economies, 30(5), 588616.

Lau, L., 1982. On identifying the degree of competitiveness from industry price and output data. Economics Letters, 10(1-2), 93-99.

Lepetit, L., Strobel, F., 2015. Bank insolvency risk and Z-score measures: A refinement. Finance Research Letters, 13, 214-224.

Lerner, A.P., 1934. The concept of monopoly and the measurement of monopoly power. Review of Economic Studies, 1(3), 157-175.

Lopez, R.A., Azzam, A.M., Liron-Espana, C., 2002. Market power and/or efficiency: A structural approach. Review of Industrial Organization, 20(2), 115-126.

Maechler, A.M., Mitra, S., Worrell, D., 2007. Decomposing financial risks and vulnerabilities in Eastern Europe. IMF Working Papers, No. 07/248, Washington.

Maudos, J., Vives, X., 2019. Competition policy in banking in the European Union. Review of Industrial Organization, 55(1), 27-54.

Mester L.J., 2008. Optimal industrial structure in banking. In: Boot, A.W.A., Thakor A.V. (Eds.), Handbook of Financial Intermediation and Banking, Amsterdam: North Holland, 133-162.

Mirza, F.M., Bergland, O., Khatoon, I., 2016. Measuring the degree of competition in Pakistan's banking industry: an empirical analysis. Applied Economics, 48(53), 5138-5151.

Mirzaei, A., Moore, T., 2014. What are the driving forces of bank competition across different income groups of countries?. Journal of International Financial Markets, Institutions and Money, 32, 38-71.

Neven, D., Roller, L.H., 1999. An aggregate structural model of competition in the European banking industry. International Journal of Industrial Organization, 17(7), 1059-1074.

Panzar, J.C., Rosse, J.N., 1987. Testing for monopoly equilibrium. Journal of Industrial Economics, 35(4), 443-456. 
Parikh, A., Shibata, M., 2004. Does trade liberalization accelerate convergence in per capita incomes in developing countries? Journal of Asian Economics, 15(1), 33-48.

Perloff, J.M., Shen, E.Z., 2012. Collinearity in linear structural models of market power. Review of Industrial Organization, 40(2), 131-138.

Petersen, M.A., Rajan, R.G., 1995. The effect of credit market competition on lending relationships. Quarterly Journal of Economics, 110(2), 407-444.

Qin, B., Shaffer, S., 2014. A test of competition in Chinese banking. Applied Economics Letters, 21(9), 602-604.

Rakshit, B., Bardhan, S., 2019. Bank competition and its determinants: Evidence from Indian banking. International Journal of the Economics of Business, 26(2), 283-313.

Rezitis, A.N., 2010. Evaluating the state of competition of the Greek banking industry. Journal of International Financial Markets, Institutions and Money, 20(1), 68-90.

Rotemberg, J., Saloner, G., 1986. A supergame-theoretic model of price wars during booms. American Economic Review, 76(3), 390-407.

Rothschild, K.W., 1942. The degree of monopoly. Economica, 9(33), 24-39.

Shaffer, S., 1989. Competition in the U.S. banking industry. Economic Letters, 29(4), 321-323.

Shaffer, S., 1993. A test of competition in Canadian banking. Journal of Money, Credit, and Banking, 25(1), 49-61.

Shaffer, S., 1999. The competitive impact of disclosure requirements in the credit card industry. Journal of Regulatory Economics, 15(2), 183-198.

Shaffer, S., 2001. Banking conduct before the European single banking license: A cross-country comparison. North American Journal of Economics and Finance, 12(1), 79-104.

Shaffer, S., 2004. Patterns of competition in banking. Journal of Economics and Business, 56(4), 287-313.

Shaffer, S., Spierdijk, L., 2015. The Panzar-Rosse revenue test and market power in banking. Journal of Banking and Finance, 61, 340-347.

Shaffer, S., Spierdijk, L., 2017. Market power: Competition among measures. In: Bikker, J.A., Spierdijk, L. (Eds.), Handbook of Competition in Banking and Finance. Cheltenham: Edward Elgar, 11-26.

Suominen, M., 1994. Measuring competition in banking: A two-product model. Scandinavian Journal of Economics, 96(1), 95-110.

Toolsema, L.A., 2002. Competition in the Dutch consumer credit market. Journal of Banking and Finance, 26(11), 2215-2229. 
Toolsema, L.A., 2004. Monetary policy and market power in banking. Journal of Economics, 83(1), 71-83.

Weill, L., 2013. Bank competition in the EU: How has it evolved?, Journal of International Financial Markets, Institutions and Money, 26, 100-112.

Weiss, L.W., 1989. A review of concentration-price studies in banking. In: Weiss L.W. (Ed.), Concentration and price. Cambridge: MIT Press.

Wolfram, C.D., 1999. Measuring duopoly power in the British electricity spot market, American Economic Review, 89(4), 805-826.

Zardkoohi, A., Fraser, D.R., 1998. Geographical deregulation and competition in U.S. banking markets. The Financial Review, 33(2), 85-98. 
Appendix A-Calculation of the standard errors of the elasticities

The $z$-values of the elasticities reported in Table 2 - i.e., the own-price and cross-price elasticities of demand, $\varepsilon_{Q, P}$ and $\varepsilon_{Q, Z}$, and the price elasticities with respect to the determinants of the conduct parameter, $\varepsilon P, H H I, E P, B R P C, \varepsilon P, E Q A S T, E P, I N E F F, \varepsilon P, Z S C O R E$, and $\varepsilon P, G D P G R$ - are based on standard errors calculated by the delta method.

Let $y=f(x ; \beta)$ be the generic equation of our two-equation model, where $x$ is a $J \times 1$ vector of covariates and $\beta$ is a $K \times 1$ vector of parameters (and where the error term is omitted). ${ }^{3}$

Since the elasticities of $y$ with respect to the $J$ covariates are functions of the parameters, they can be written as $\varepsilon_{y, x}=g(\beta)$, where $g(\cdot)$ is a $J \times 1$ vector-valued function. ${ }^{4}$ Accordingly, their variance-covariance matrix is $\Phi=H(\beta) \Sigma H^{\prime}(\beta)$, where $H(\beta)=\partial \varepsilon_{y, x} / \partial \beta^{\prime}$ while $\Sigma$ denotes the variance-covariance matrix of $\beta .^{5}$

Hence, the standard error of the elasticity of $y$ with respect to the $j$-th covariate turns out to be $\phi_{\varepsilon_{y, x_{j}}}=h_{j}{ }^{\prime}(\beta) \Sigma h_{j}(\beta)$, where $h_{j}(\beta)$ is the $j$-th row of $H(\beta)$.

Starting from (7), we can write the elasticity of demand $Q$ with respect to price $P$ as

$$
\varepsilon_{Q, P}=a_{1} P
$$

and the parameters vector as

$$
\beta_{1}=\left[\begin{array}{lllll}
a_{0} & a_{1} & a_{2} & a_{3} & a_{4}
\end{array}\right]^{\prime}
$$

It follows that

$$
\partial \varepsilon_{Q, P} / \partial \beta_{1}^{\prime}=\left[\begin{array}{lllll}
0 & P & 0 & 0 & 0
\end{array}\right]^{\prime}
$$

and that

$$
\phi_{\varepsilon_{Q, P}}=\left[\begin{array}{lllll}
0 & P & 0 & 0 & 0
\end{array}\right]^{\prime} \Sigma\left[\begin{array}{lllll}
0 & P & 0 & 0 & 0
\end{array}\right]=P^{2} \sigma_{22}=P^{2} \sigma_{a_{1}} .
$$

A similar reasoning leads to $\varepsilon_{Q, Z}=a_{2} Z$ and $\phi_{\varepsilon_{Q, Z}}=Z^{2} \sigma_{a_{2}}$.

As to the elasticity of price with respect to the determinants of the behavioural index, let us consider the generic variable $K$ (with $K=H H I, B R P C, E Q A S T$, INEFF, ZSCORE, GDPGR). Its elasticity can be calculated from (14) as

\footnotetext{
${ }^{3}$ If the model is non-linear, it may happen that $j \neq k$.

${ }^{4}$ Of course, elasticities also depend on covariates $x$. However, so as to simplify notation, we omit $x$ among the arguments of $g(\cdot)$.

${ }^{5}$ See Greene (2012), pp. 1083.
} 


$$
\varepsilon_{P, K}=-\lambda_{h} \frac{K}{a_{1} P},
$$

where $h=1, \ldots, 6$, while the parameters vector is

$$
\beta_{2}=\left[\begin{array}{lllllllllllllll}
a_{1} & b_{Q} & b_{Q Q} & b_{Q 1} & b_{Q 2} & b_{T Q} & \lambda_{1} & \lambda_{2} & \lambda_{3} & \lambda_{4} & \lambda_{5} & \lambda_{6} & \lambda_{7} & \ldots & \lambda_{19}
\end{array}\right]^{\prime},
$$

with $\lambda_{7} \ldots \lambda_{19}$ representing the parameters associated to the year dummy variables.

The standard error of the elasticity of $P$ with respect to $K$ is $\varphi_{\varepsilon_{P, K}}=h^{\prime}\left(\beta_{2}\right) \Sigma h\left(\beta_{2}\right)$, where

$$
h\left(\beta_{2}\right)=\left[\frac{\partial \varepsilon_{P, K}}{\partial a_{1}} \frac{\partial \varepsilon_{P, K}}{\partial b_{Q}} \frac{\partial \varepsilon_{P, K}}{\partial b_{Q Q}} \frac{\partial \varepsilon_{P, K}}{\partial b_{Q 1}} \frac{\partial \varepsilon_{P, K}}{\partial b_{Q 2}} \frac{\partial \varepsilon_{P, K}}{\partial b_{T Q}} \frac{\partial \varepsilon_{P, K}}{\partial \lambda_{1}} \ldots \frac{\partial \varepsilon_{P, K}}{\partial \lambda_{19}}\right]^{\prime}
$$

The terms in $h\left(\beta_{2}\right)$ correspond to: ${ }^{6}$

$$
\begin{array}{rlrl}
\frac{\partial \varepsilon_{P, K}}{\partial a_{1}}=\frac{\lambda_{h} K}{a_{1}^{2} P}\left(1+\frac{\lambda}{a_{1} P}\right) ; & \frac{\partial \varepsilon_{P, K}}{\partial b_{Q}}=\lambda_{h} K \frac{T C}{Q} \frac{1}{a_{1} P^{2}} ; & \frac{\partial \varepsilon_{P, K}}{\partial b_{Q Q}}=\lambda_{h} K \frac{T C}{Q} \frac{\ln Q}{a_{1} P^{2}} ; \\
\frac{\partial \varepsilon_{P, K}}{\partial b_{Q 1}}=\lambda_{h} K \frac{T C}{Q} \frac{\ln \left(W_{1} / W_{3}\right)}{a_{1} P^{2}} ; & \frac{\partial \varepsilon_{P, K}}{\partial b_{Q 2}}=\lambda_{h} K \frac{T C}{Q} \frac{\ln \left(W_{2} / W_{3}\right)}{a_{1} P^{2}} ; & \frac{\partial \varepsilon_{P, K}}{\partial b_{T Q}}=\lambda_{h} K \frac{T C}{Q} \frac{\ln T I M E}{a_{1} P^{2}} ; \\
\frac{\partial \varepsilon_{P, K}}{\partial \lambda_{h}}=-\frac{K}{a_{1} P}\left(1+\frac{\lambda_{h} K}{a_{1} P}\right) ; & \frac{\partial \varepsilon_{P, K}}{\partial \lambda_{-h}}=-\frac{\lambda_{h} K}{a_{1}^{2} P^{2}} K_{-1} .
\end{array}
$$

In the last expression, $K_{-1}$ denotes the generic determinant of the conduct index different from $K$, while $\lambda_{-h}$ indicates its coefficient.

\footnotetext{
${ }^{6}$ It should be recalled that $P$, in turn, is a function of the parameters vector.
} 
Table 1 - Summary statistics and data description

\begin{tabular}{lcccccc}
\hline Variable & Mean & Std. dev. & Min & Median & Max & N. obs. \\
\hline$Q$ & $1,285,926$ & $1,511,968$ & $25,620.14$ & 514,078 & $5,269,891$ & 169 \\
$P$ & 3.7928 & 1.2796 & 1.4083 & 3.6313 & 7.0233 & 169 \\
$Z$ & 3.2012 & 2.8521 & -0.2500 & 3.0000 & 22.5000 & 169 \\
$P O P$ & 25.3212 & 26.6819 & 2.0103 & 10.7965 & 83.0772 & 169 \\
YPC & 28.7013 & 9.6959 & 11.9576 & 31.3199 & 60.2514 & 169 \\
TC & $63,866.88$ & $71,672.15$ & 780.24 & $26,034.81$ & 313,001 & 169 \\
$W_{1}$ & 1.7645 & 1.2423 & 0.0948 & 1.4871 & 4.6728 & 169 \\
$W_{2}$ & 0.0879 & 0.0409 & 0.0245 & 0.0865 & 0.1992 & 169 \\
$W_{3}$ & 0.0050 & 0.0016 & 0.0014 & 0.0051 & 0.0087 & 169 \\
TIME & 7.0000 & 3.7528 & 1 & 7 & 13 & 169 \\
HHI & 0.1151 & 0.0810 & 0.0183 & 0.1061 & 0.3880 & 169 \\
BRPC & 0.4782 & 0.2267 & 0.0900 & 0.4318 & 1.2207 & 169 \\
EQAST & 7.0482 & 2.4615 & 2.7974 & 6.7092 & 15.0809 & 169 \\
INEFF & 0.5204 & 0.0996 & 0.2961 & 0.5209 & 0.9270 & 169 \\
ZSCORE & 1.0789 & 1.5064 & 0.0057 & 0.4436 & 9.2266 & 169 \\
GDPGR & 1.2402 & 3.4996 & -9.1325 & 1.5163 & 25.1626 & 169 \\
\hline
\end{tabular}

\begin{tabular}{lll}
\hline Variable & Description & Source \\
\hline$Q$ & Loans (million euro at constant 2010 values) & ECB (BSI database) \\
\hline$P$ & Interest rate on loans (\%, yearly average of monthly figures) & ECB (MIR database) \\
\hline$Z$ & Interest rates on long-term government bonds (\%) & Eurostat \\
\hline$P O P$ & Average population during year (million units) & Eurostat \\
\hline$Y P C$ & Per capita GDP (thousand euro at constant 2010 values) & Eurostat \\
\hline$T C$ & Total costs (million euro at constant 2010 values) & ECB (CBD database) \\
\hline$W_{1}$ & Interest rate on deposits (\%, yearly average of monthly figures) & ECB (MIR database) \\
\hline$W_{2}$ & Staff costs/Employees (million euro at constant 2010 values) & ECB (CBD and SSI databases) \\
\hline$W_{3}$ & Other administrative expenses/Total assets (\%) & ECB (CBD database) \\
\hline$T I M E$ & Time trend & - \\
\hline$H H I$ & Herfindahl index for total assets & ECB (SSI database) \\
\hline$B R P C$ & Branches per thousand adult inhabitants (units) & ECB (SSI database) and Eurostat \\
\hline$E Q A S T$ & Total equity/Total assets $(\%)$ & ECB (CBD database) \\
\hline$I N E F F$ & Non-interest expenses/Total operating income & ECB (CBD database) \\
\hline$Z S C O R E$ & Country-level Z-score & Own calculation on ECB data \\
\hline GDPGR & Real GDP growth rate (\%) & Eurostat \\
\hline
\end{tabular}


Table 2 - System estimation results

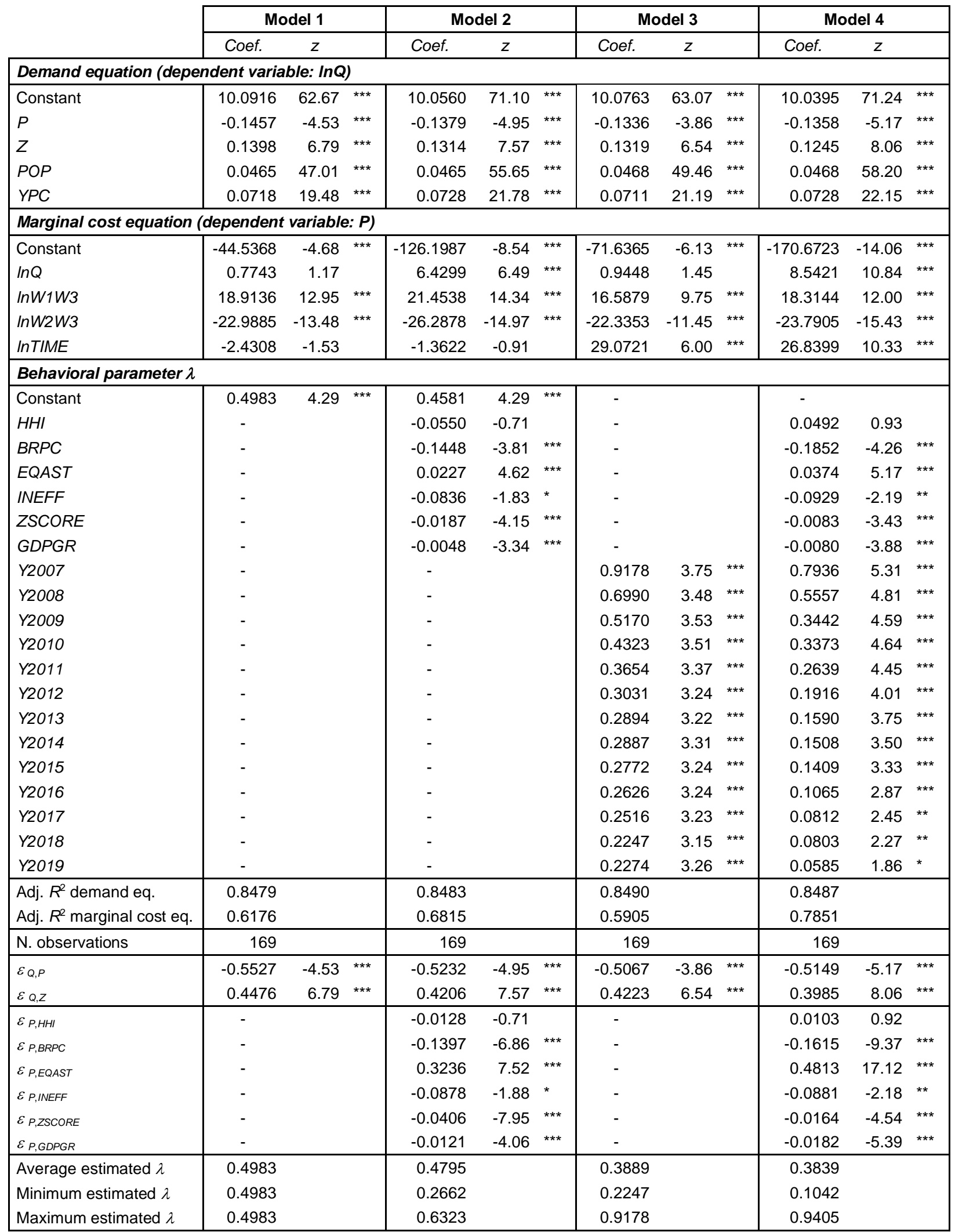

The systems have been estimated by non-linear three-stage least squares with optimal weighting matrix and robust standard errors.

The instruments used are: levels and logs of first-lagged $Q$ and $P$; levels and logs of $Z, P O P, Y P C, T C, W 1, W 2, W 3, T I M E$ (in Models 2 and 4, further instruments are: levels and logs of HHI, BRPC, EQAST, INEFF, ZSCORE, GDPGR; in Models 3 and 4, further instruments are: levels of year dummies).

The elasticities have been computed at mean values of the variables (their $z$-values are based on standard errors calculated by the delta method).

Significance for the parameter estimates: $* * *=1 \%$ level; $* *=5 \%$ level; $*=10 \%$ level. 
Table 3 - Estimated values of $\lambda$ by country and year (Model 4)

\begin{tabular}{|c|c|c|c|c|c|c|c|c|c|c|c|c|c|c|}
\hline $\begin{array}{l}\text { Year } \\
\text { Country }\end{array}$ & 2007 & 2008 & 2009 & 2010 & 2011 & 2012 & 2013 & 2014 & 2015 & 2016 & 2017 & 2018 & 2019 & $\begin{array}{c}\text { Country } \\
\text { avg. }\end{array}$ \\
\hline Austria & 0.8537 & 0.5365 & 0.4106 & 0.3836 & 0.2791 & 0.2468 & 0.3177 & 0.2935 & 0.3011 & 0.2852 & 0.2798 & 0.2883 & 0.2589 & 0.3642 \\
\hline Belgium & 0.8248 & 0.4880 & 0.3454 & 0.3223 & 0.2465 & 0.2261 & 0.3131 & 0.3074 & 0.3015 & 0.2817 & 0.2605 & 0.2567 & 0.2301 & 0.3388 \\
\hline Finland & 0.9365 & 0.6786 & 0.5631 & 0.4270 & 0.3154 & 0.2651 & 0.2725 & 0.2416 & 0.2761 & 0.2433 & 0.1983 & 0.2291 & 0.2367 & 0.3756 \\
\hline France & 0.7854 & 0.4528 & 0.3108 & 0.3627 & 0.2783 & 0.2312 & 0.2180 & 0.1989 & 0.2073 & 0.1925 & 0.1262 & 0.1042 & 0.1174 & 0.2758 \\
\hline Germany & 0.7622 & 0.4566 & 0.3303 & 0.3425 & 0.2699 & 0.2261 & 0.2172 & 0.2203 & 0.2212 & 0.1788 & 0.2353 & 0.2480 & 0.2273 & 0.3027 \\
\hline Greece & 0.8977 & 0.5813 & 0.4582 & 0.4487 & 0.3777 & 0.2955 & 0.3883 & 0.3818 & 0.4333 & 0.4287 & 0.4471 & 0.3464 & 0.3419 & 0.4482 \\
\hline Ireland & 0.8403 & 0.5741 & 0.4047 & 0.3441 & 0.3207 & 0.2758 & 0.3391 & 0.4406 & 0.3624 & 0.4988 & 0.5108 & 0.5038 & 0.4636 & 0.4522 \\
\hline Italy & 0.9395 & 0.6001 & 0.4545 & 0.4616 & 0.3825 & 0.3524 & 0.3054 & 0.3038 & 0.3080 & 0.2522 & 0.2733 & 0.2663 & 0.2495 & 0.3961 \\
\hline Netherlands & 0.8308 & 0.5131 & 0.3974 & 0.4464 & 0.3664 & 0.3273 & 0.2987 & 0.3012 & 0.3044 & 0.2729 & 0.2520 & 0.2622 & 0.2398 & 0.3702 \\
\hline Portugal & 0.8630 & 0.5267 & 0.3668 & 0.3142 & 0.2345 & 0.2370 & 0.2875 & 0.2874 & 0.3091 & 0.2614 & 0.2951 & 0.3068 & 0.2967 & 0.3528 \\
\hline Slovakia & 0.9009 & 0.7558 & 0.6893 & 0.5949 & 0.5931 & 0.5618 & 0.5472 & 0.4818 & 0.4252 & 0.3910 & 0.3747 & 0.3443 & 0.3616 & 0.5401 \\
\hline Slovenia & 0.9405 & 0.6493 & 0.5233 & 0.4392 & 0.3698 & 0.3328 & 0.4303 & 0.4689 & 0.4960 & 0.4824 & 0.4448 & 0.4402 & 0.4213 & 0.4953 \\
\hline Spain & 0.7715 & 0.4343 & 0.2910 & 0.2461 & 0.1976 & 0.1470 & 0.2588 & 0.2519 & 0.2214 & 0.2122 & 0.1902 & 0.2038 & 0.1899 & 0.2781 \\
\hline Yearly avg. & 0.8574 & 0.5575 & 0.4266 & 0.3949 & 0.3255 & 0.2865 & 0.3226 & 0.3215 & 0.3206 & 0.3062 & 0.2991 & 0.2923 & 0.2796 & \\
\hline
\end{tabular}


Table 4 - Tests of convergence of $\lambda$

\begin{tabular}{|l|lll|}
\hline & Coef. & $t$ \\
\hline \multicolumn{4}{|l|}{$\beta$-convergence (dep. var.: $\left.\ln \left(\lambda_{c, t}\right)-\ln \left(\lambda_{c, t-1}\right)\right)$} \\
\hline Constant $\left(c_{0}\right)$ & -0.3134 & $-7.63^{* * *}$ \\
$\ln \left(\lambda_{c, t-1}\right)\left(c_{1}\right)$ & $-0.3773^{*}$ & $-13.35^{* * *}$ \\
\hline Adj. $R^{2}$ & 0.5254 & & \\
\hline$\sigma$-convergence (dep. var.: $\left.\Delta W_{c, t}\right)$ & & \\
\hline Constant $\left(d_{0}\right)$ & 0.1303 & $3.35^{* * *}$ \\
$W_{c, t-1}\left(d_{1}\right)$ & -0.2710 & $-4.79^{* * *}$ \\
\hline Adj. $R^{2}$ & 0.1074 & & \\
\hline Obs. & 156 & \\
\hline
\end{tabular}

In the test of $\sigma$-convergence, $\Delta W_{c, t}=W_{c, t}-W_{c, t-1}$, with $W_{\mathrm{ct}}=\ln \left(\lambda_{c, t}\right)-\operatorname{mean}\left(\ln \left(\lambda_{t}\right)\right)$.

Both equations include a set of country fixed effects (coefficients estimates are not reported).

Significance for the parameter estimates: $* * *=1 \%$ level; $* *=5 \%$ level; $*=10 \%$ level. 
Figure 1 - Estimated average country-level demand, marginal cost and marginal revenue for the EU banking industry (based on Model 1)

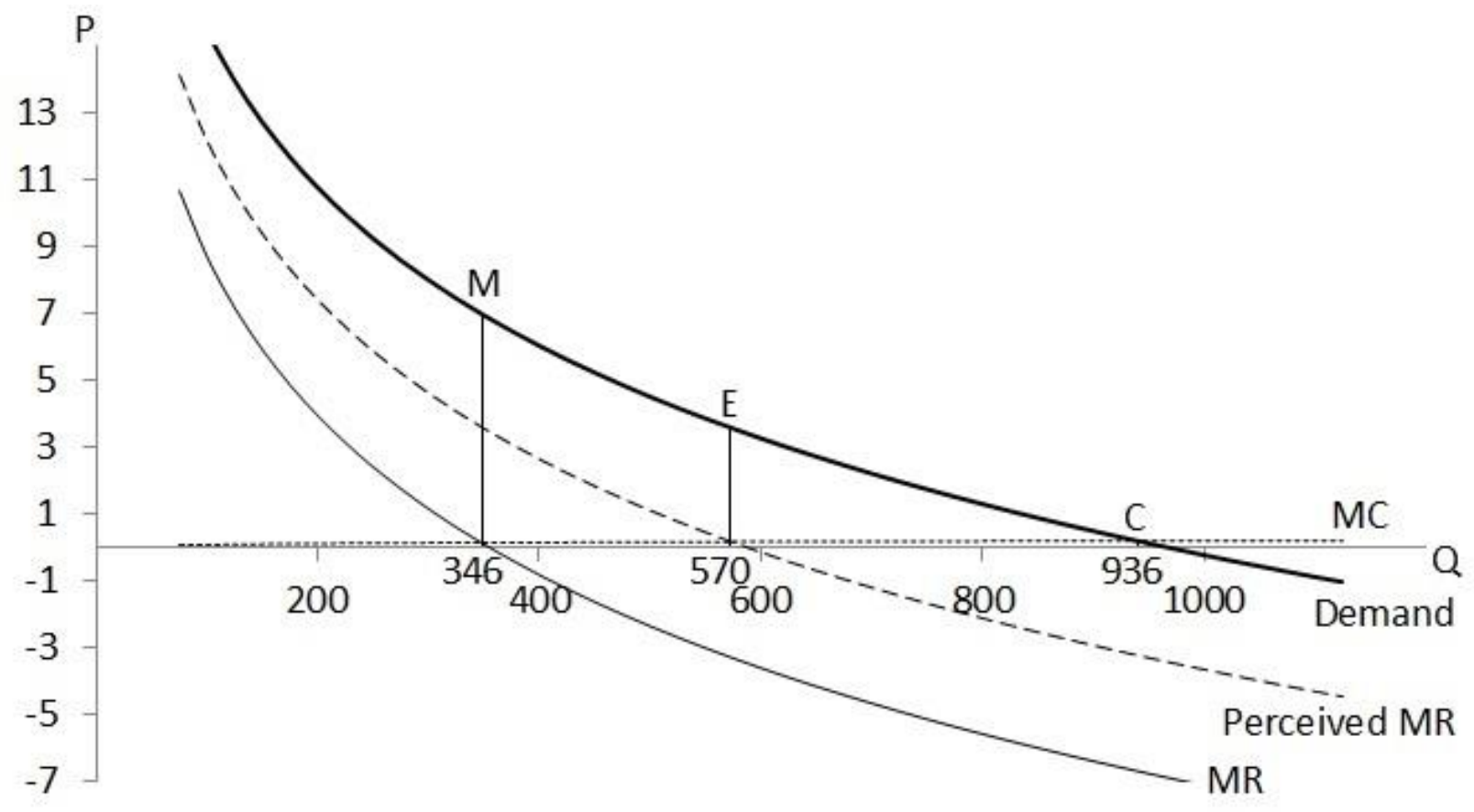

